\title{
Prevalence of Sub Clinical Mastitis in an Organized Buffalo Dairy Farm along with Antibiogram
}

\author{
Rajesh Chhabra $^{1 *}$, Garima Shrinet ${ }^{2}$, Rahul Yadav ${ }^{1}$ and Saurab Jyoti Talukdar ${ }^{2}$ \\ ${ }^{1}$ College Central laboratory, Lala Lajpat Rai University of Veterinary and Animal Sciences \\ Hisar, Haryana, India \\ ${ }^{2}$ Department of Veterinary Microbiology, Lala Lajpat Rai University of Veterinary and \\ Animal Sciences Hisar, Haryana, India \\ *Corresponding author
}

\begin{tabular}{|l|}
\hline Ke y w o r d s \\
Mastitis, Buffalo, \\
Antibiogram, \\
$\begin{array}{l}\text { Somatic cell count, } \\
\text { organized dairy } \\
\text { farm }\end{array}$ \\
\hline Article Info \\
\hline $\begin{array}{l}\text { Accepted: } \\
\text { 15 December 2019 } \\
\text { Available Online: } \\
\text { 20 January 2020 }\end{array}$ \\
\hline
\end{tabular}

\section{A B S T R A C T}

The present study was aimed to determine prevalence and etiology of sub clinical mastitis in an organized buffalo dairy farm of LUVAS, Hisar, India along with antibiogram against their respective causative organisms. A total of 401 quarter milk samples were collected from 102 apparently healthy buffaloes. According to the IDF criteria the percent animal wise prevalence of sub clinical mastitis on the basis of somatic cell count (SCC) $(>500000 / \mathrm{ml})$ was 2.94 , whereas on the basis of cultural examination it was 29.41. However, the quarter wise percent prevalence was 18.20 and 0.74 based on cultural positivity and SCC, respectively. Out of 73 culturally positive quarters, a total of 96 organisms were recovered. Of these $63.54 \%$ were Staphylococcus species, $36.46 \%$ were Streptococcus species while $13.54 \%$ had mixed infection of both Staphylococcus and Streptococcus species. Based on the IDF criteria the quarter wise percent prevalence of sub clinical, latent and nonspecific mastitis was $0.74 \%, 17.45 \%$ and $0 \%$, respectively. The antibiogram study revealed that the highest percent sensitivity of the Staphylococcus species isolates was $73.44 \%$ and $75 \%$ for moxifloxacin and enrofloxacin, respectively. Similarly the highest sensitivity of Streptococcus species isolates was $71.88 \%$ for moxifloxacin.

\section{Introduction}

Mastitis is defined as the infection of the udder tissue having inflammatory responses. It has been reported in different animal species but is major concern in cattle and buffalo which are common dairy animals.
Mastitis can be classified into two types namely clinical and subclinical. Clinical mastitis is characterized by acute onset, altered milk composition and appearance, decreased milk production and also the presence of the cardinal signs of inflammation in mammary glands. Whereas the subclinical 
mastitis has no visible signs are seen on the udder or in the milk, but the milk production decreases and the somatic cell count increases (Abebe et al., 2016). Subclinical mastitis has more economical impact due to constantly decreased milk production, higher prevalence and longer devastating effects (Mungube et al., 2005).

Mastitis in buffalo herds have been reported to cause high antibiotic resistance due to which infection persists for longer duration and cause severe economic losses. The economic losses may be in terms of decreased quantity and quality of milk production, as well as increased costs of treatment and control. Although, buffalo has been traditionally considered less susceptible to mastitis (Wanasinghe, 1985) is still most difficult to cure due to high cost of treatment, antibiotic resistance and high rate of multiplicating microorganism in nutritive media like milk. (Fagiolo and Lai, 2007). The total buffalo population in India is 108.7 million which is the largest in the world, among which $3.84 \%$ and $24.43 \%$ of buffaloes are affected with clinical and subclinical mastitis respectively every year (Singh and Singh, 1994). The annual economic losses due to mastitis are estimated to be Rs. 7165.51 crores in India, out of which $57.93 \%$ (Rs. 4151.16 crores losses) has been attributed to subclinical mastitis (Reshi et al., 2015). Sharma et al., 2018 have also reported that subclinical mastitis is more prevalent than clinical mastitis in buffalo farms accounting for $33.76 \%$ and $18.17 \%$ cases, respectively. Sub clinical mastitis drastically reduces milk yield, and usually precedes the clinical form which is the basis of herd problems when mastitis outbreaks occur.

The most common etiological agents of mastitis in high yielder riverine buffalo (murrah and nili ravi) are Staphylococcus aureus followed by Streptococcus agalactiae,
Streptococcus dysgalactiae and Streptococcus uberis (Fagiolo and Lai, 2007). Mastitis leads to reservoir of infection for human beings through increased amounts of drug residues in milk, increased antimicrobial resistance of the organisms in animals treated with antibiotics. Mastitis specifically sub clinical type is well known for development of multiple drug resistance strains and emergence of new pathogens due to indiscriminate use of antimicrobials over long period (Raberg et al., 2007). Hence it becomes important to diagnose the etiological agent of subclinical mastitis and subsequently the effective antimicrobial to prevent the indiscriminate use of antibiotics.

Thus the present study was designed to determine the prevalence of subclinical mastitis in organized buffalo dairy farm. The study also included the determination of organisms responsible to its causation and antimicrobial sensitivity towards common and newer antimicrobials.

\section{Materials and Methods}

\section{Source of milk samples and collection method}

A total of 401 quarters of buffalo milk samples from 102 apparently healthy buffaloes of organized dairy farm, Lala Lajpat Rai University of Veterinary and Animal Sciences (LUVAS), Hisar, India were screened for sub clinical mastitis.

Milk was collected under aseptic conditions. For this the udders of buffaloes were cleaned thoroughly with dilute potassium permanganate solution. After washing hands properly with soap and water the teats were disinfected with $70 \%$ alcohol. There after first three to four milk stripping were discarded and 15-20 ml milk sample of each quarter was collected separately in a sterilized test tube. 
These test tubes were marked as right fore $(\mathrm{RF})$, right hind $(\mathrm{RH})$, left fore (LF) and left hind (LH). Each test tube was given the number possessed by the animal.

\section{Bacterial examination}

According to International Dairy Federation Criteria the prevalence of sub-clinical mastitis should be determined on the basis of on bacteriological examination of milk and somatic cell count (SCC).

For bacteriological examination, the milk samples were shaken thoroughly to remove the fat and $10 \mu \mathrm{l}$ of milk was streaked on both 5\% sheep blood agar and MacConkey's lactose agar plates. The plates were incubated aerobically at $37^{\circ} \mathrm{C}$ for 24 to 48 hours. The resulting growth was sub-cultured on blood agar for purification of isolates and bacterial isolates were further subjected for identification and confirmation on the basis of gram's staining, morphology and colony characteristics. All the isolates were identified following standard bacteriological procedures as per Cruickshank et al., (1975).

\section{Somatic cell counts}

The SCC was performed as per the original method introduced by Schalm et al., (1971). It involved the spreading of $0.01 \mathrm{ml}$ milk over an area of $1 \mathrm{~cm}^{2}$ on a microscope slide, followed by fixing, defatting and staining with the Newman-Lampert stain (HiMedia Laboratories Ltd., Mumbai).

\section{Antimicrobial sensitivity testing}

The antimicrobial sensitivity testing was performed as per disc-diffusion method suggested by Bauer et al., (1966). The interpretation was made based on the zone size interpretation chart provided by the manufacturer of discs. The fifteen different antimicrobials (Hi Media Laboratories
Ltd.,Mumbai) namely Penicillin (10 I.U), Streptomycin $(10 \mu \mathrm{g})$, Moxifloxacin $(5 \mu \mathrm{g})$, Oxytetracycline $(30 \mu \mathrm{g})$, Chloramphenicol $(30 \mu \mathrm{g})$, Ampicillin $(10 \mu \mathrm{g})$, Neomycin (10 $\mu \mathrm{g})$, Cloxacillin, Enrofloxacin $(10 \mu \mathrm{g})$, Gentamicin $(50 \mu \mathrm{g})$, Amikacin $(30 \mu \mathrm{g})$, Amoxycillin $(30 \mu \mathrm{g})$, Ceftriaxone $(30 \mu \mathrm{g})$, Cefoperazone $(75 \mu \mathrm{g})$ and Levofloxacin (5 $\mu \mathrm{g})$ were used. The results were recorded as sensitive, intermediate and resistant.

\section{Results and Discussion}

Bacterial culture examination on 401 quarters of 102 buffaloes showed that 73 quarters were culturally positive and total of 96 organisms were isolated from these quarters. Out of these $61(63.54 \%)$ were positive for Staphylococcus species, 35 (36.46\%) were positive for Streptococcus species while 13 (13.54\%) quarters had mixed infection of Staphylococcus and Streptococcus species combined.

The result of somatic cell count (SCC) in the organized buffalo farm is presented in table 1. The animal wise percent prevalence of subclinical mastitis was found to be $2.94 \%$ on the basis of SCC $(>500000 / \mathrm{ml})$ while on the basis of cultural examination was $29.41 \%$. Whereas the quarter-wise percent prevalence on the basis of SCC was $18.02 \%$ while on the basis of bacteriological examination was $0.74 \%$.

According to IDF criteria based on SCC and bacterial examination, the mastitis can be classified as sub clinical when SCC is above $500,000 / \mathrm{ml}$ of milk and culturally positive. The latent mastitis occurs when SCC below $500,000 / \mathrm{ml}$ of milk but culturally positive. Mastitis is said to be nonspecific when culturally negative and SCC above $500,000 / \mathrm{ml}$. In the present study the $0.74 \%$, $17.45 \%$ and $0 \%$ of the quarters were found to be suffering with sub clinical, latent and nonspecific mastitis respectively. 
The antibiogram of different organisms isolated from the 73 culturally positive quarters is in terms of percent sensitivity is presented in table 2. About $73.44 \%$ and $75 \%$ of the Staphylococcus species isolated revealed high sensitivity towards moxifloxacin and enrofloxacin, respectively. However, only $1.56 \%$ and $7.81 \%$ of the Staphylococcus isolates were sensitive to oxytetracycline and streptomycin, respectively. While $71.88 \%$ of the Streptococcus species isolated revealed higher sensitivity towards moxifloxacin. Whereas around $68.75 \%$ Streptococcus species had higher sensitivity towards enrofloxacin. In the Streptococcus species the least effective antimicrobials were oxytetracycline and Streptomycin with only $1.56 \%$ as percent sensitivity. Both Staphylococcus and Streptococcus species showed lowered sensitivity towards amikacin with percent sensitivity of 18.75 and $12.50 \%$, respectively. Similarly sensitivity towards other antibiotics was found little. It was interesting to note that none of the antimicrobials had 100 percent sensitivity towards either Staphylococcus or Streptococcus species.

Table.1 Prevalence of sub clinical mastitis based on IDF criteria in buffalo dairy farm, LUVAS

\begin{tabular}{|c|c|c|c|c|c|c|}
\hline \multirow{2}{*}{$\begin{array}{l}\text { Animals } \\
\text { culturally } \\
\text { positive }\end{array}$} & \multirow{2}{*}{$\begin{array}{l}\text { Animals } \\
\text { showing } \\
\text { SCC > } 5 \\
\text { lac/ml }\end{array}$} & \multirow{2}{*}{$\begin{array}{l}\text { Quarters } \\
\text { culturally } \\
\text { positive }\end{array}$} & \multicolumn{4}{|c|}{ Quarters showing } \\
\hline & & & $\begin{array}{l}\text { SCC > } 5 \\
\text { lac/ml }\end{array}$ & $\begin{array}{l}\mathrm{SCC}>5 \mathrm{lac} / \mathrm{ml} \\
\text { and culturally } \\
\text { positive }\end{array}$ & $\begin{array}{l}\mathrm{SCC}<5 \mathrm{lac} / \mathrm{ml} \\
\text { and culturally } \\
\text { positive }\end{array}$ & $\begin{array}{l}\mathrm{SCC}>5 \mathrm{lac} / \mathrm{ml} \\
\begin{array}{l}\text { and } \\
\text { negative }\end{array}\end{array}$ \\
\hline $\begin{array}{l}30 \\
(29.41 \%)\end{array}$ & $\begin{array}{l}03 \\
(2.94 \%)\end{array}$ & $\begin{array}{l}73 \\
(18.20 \%)\end{array}$ & $\begin{array}{l}03 \\
(0.74 \%)\end{array}$ & $\begin{array}{l}03 \\
(0.74 \%)\end{array}$ & $\begin{array}{l}70 \\
(17.45 \%)\end{array}$ & $\begin{array}{l}0 \\
(0 \%)\end{array}$ \\
\hline
\end{tabular}

Table.2 Percent antimicrobial sensitivity of bacterial isolates

\begin{tabular}{|c|c|c|}
\hline \multirow{2}{*}{ Antimicrobial Drug } & \multicolumn{2}{|c|}{ Percent sensitivity } \\
\cline { 2 - 3 } & $\begin{array}{c}\text { Staphylococci } \\
(\mathbf{n = 6 1})\end{array}$ & $\begin{array}{c}\text { Streptococci } \\
(\mathbf{n = 3 5})\end{array}$ \\
\hline Penicillin & 23.44 & 21.88 \\
\hline Streptomycin & 7.81 & 1.56 \\
\hline Moxifloxacin & 73.44 & 71.88 \\
\hline Oxytetracycline & 1.56 & 1.56 \\
\hline Chloramphenicol & 45.31 & 40.63 \\
\hline Ampicillin & 23.44 & 21.88 \\
\hline Neomycin & 34.38 & 34.38 \\
\hline Cloxacillin & 31.25 & 25.00 \\
\hline Enrofloxacin & 75.00 & 68.75 \\
\hline Gentamicin & 32.81 & 25.00 \\
\hline Amikacin & 18.75 & 12.50 \\
\hline Amoxycillin & 31.25 & 25.00 \\
\hline Ceftriaxone & 28.13 & 26.56 \\
\hline Cefoperazone & 39.06 & 31.25 \\
\hline Levofloxacin & 46.88 & 37.50 \\
\hline
\end{tabular}


India is known for the largest buffalo population of the world that includes high milk yielder 'Black Gold' Murrah buffalo. Therefore, disease like mastitis becomes economically devastating for the buffalo dairy industry. The cost of treatment is also high and even leads to antimicrobial resistances. Hence, mastitis in dairy industry is said to be the top ranking infectious disease (Zecconi, 2003) leading to heavy economic losses. Mastitis is known to be caused by over 150 different contagious or environmental microorganisms (Kuang et al., 2009), but the most common pathogens of economic and epidemiological importance are species of staphylococci, streptococci and coliforms (Shome et al., 2011).

In the present study a total of 96 microorganisms were isolated from 73 quarters chiefly Staphylococcus and Streptococcus species and their mixed infection, which are contagious bacteria causing mastitis. These infections are usually spread from animal to animal at the time of milking. These finding were similar to that of Bansal et al., (1995), Petzer et al., (2009) and Pankaj et al., (2013). Among the 96 microorganisms, 61 were Staphylococcus species isolates which showed high prevalence of Staphylococcus species. The high prevalence of staphylococci has also been reported by several other workers in India (Kalorey et al., 1983; Javed and Siddique, 1999; Kaya et al., 2000; Sharma et al., 2007) and abroad (Tenhagen et al., 2009 and Nickerson and Stephen, 2009). The prevalence of mastitis varies with breed, age, lactation and season (Rani et al., 2008) therefore distribution of pathogens changes over time hence, the study suggests that bacteriological examination at the herd level must be taken regularly to monitor udder health status. Sumathi et al., (2008) reported that coliform mastitis indicate poor hygienic conditions as $E$. coli originates from the environment and infects the udder via teat canal. Higher incidence of sub clinical mastitis via environmental pathogens may be due to poor animal housing and bedding practices. In the present study no isolation of environmental pathogens of mastitis such as $E$. coli etc. indicated good hygiene condition of animal house.

On the basis of IDF criteria the prevalence of quarter wise subclinical mastitis was $0.74 \%$ whereas the latent mastitis was $17.45 \%$ which was in contrast to high sub clinical mastitis prevalence reported by several other workers (Kalorey et al., 1983; Chavan et al., 2007 and Sharma et al., 2018). These variations in the prevalence rates of sub clinical mastitis could be due to difference in management and hygienic practices adopted in different dairy herds. While other factors like breed, milk yield, stage of lactation (Sharma et al., 2007) and udder morphology could also lead to difference in prevalence. The high latent infection can also denote possibility of teat canal infections serving as a potential source of infection to the milk secretory tissue (Nickerson et al., 1986). None of the quarters were affected with nonspecific mastitis could be due to the failure to detect pathogens because of intermittent excretion of the organisms or their disappearance because of spontaneous recovery (Sindhu et al., 2009).

The indiscriminate use of antibiotics in treatment of mastitis has led to antimicrobial resistance and even a reservoir of infection for humans through antimicrobial residue in the milk of the treated animals. In Staphylococci infections around $73.44 \%$ and $75 \%$ of the isolates were sensitive to moxifloxacin and enrofloxacin, respectively. This depicts an increase in antimicrobial resistance in Staphylococci infections as previous studies on buffalo subclinical mastitis reported higher sensitivity towards ceftriaxone, cefaperazone and ampicillin in the range from 89.56, 93.40 
and 99.62 percent, respectively (Sharma et al., 2018). In an another study, all the strains of staphylococci and streptococci were found sensitive to cloxacillin, ceftriaxone and cefoperazone (Pankaj et al., 2013) which was not observed in our study. The present study suggests that Staphylococcus and Streptococcus species isolated from buffaloes milk sample of LUVAS farm showed high sensitivity towards moxifloxacin followed by enrofloxacin. Ranjan et al., (2010) also found high sensitivity towards enrofloxacin (91.67\%) similar to the present study. This indicates that fluroquinolone group of antimicrobials which inhibit the DNA gyrase enzyme and eventually DNA and RNA synthesis are still effective against majority of Staphylococcus and Streptococcus species isolates from buffalo mastitis cases.

Earlier studies have reported higher sensitivity towards chloramphenicol and oxytetracycline to be in the range from 81.59 to $82.46 \%$ (Sharma et al., 2018) which was not seen in the present study. The sensitivity towards chloramphenicol and oxytetracycline was much reduced in the range $40.5 \%$ to as low as $1.56 \%$ which may indicate multiple drug resistance as the gene encoding for resistance to chloramphenicol and oxytetracycline are present on the same plasmid (Chopra and Roberts, 2001). Thus in contrast to the earlier studies the current study antibiogram indicated reduced sensitivity towards newer antibiotics like third and fourth generation cephalosporins and older antibiotics such as penicillin and streptomycin. This demand for rationalisation of use of antimicrobials in the treatment of mastitis especially in context to sub clinical mastitis cases in buffaloes. The evolution of drug resistant organisms leading to mastitis due to indiscriminate use of broad spectrum antibiotics is well established therefore, antimicrobial sensitivity is suggested before treatment. Above all distribution of pathogens changes over time from different farms, regions, states and countries hence bacteriological examination at herd level must be performed regularly to monitor udder health status and sub clinical mastitis for early, prompt and specific treatment.

\section{Acknowledgments}

The authors acknowledge the Head of the Department, Department of Livestock Production and Management (LPM), LUVAS, Hisar for permission to collect milk samples from the buffalo farm.

\section{References}

Abebe, R., Hatiya, H., Abera, M., Megersa, B. and Asmare, K. 2016. Bovine mastitis: prevalence, risk factors and isolation of Staphylococcus aureus in dairy herds at Hawassa milk shed, South Ethiopia. BMC Vet. Res. 12, 270.

Bansal, B.K., Singh, K.B., Rohan, R., Joshi, D.V., Nauriyal, D.C. and Rajesh Mohan. 1995. Incidence of sub clinical mastitis in some cow and buffalo herds in Punjab. J. Res. Punjab Agri. Uni. 32, 79-81.

Bauer, A.W., Kirby, W.W.M., Sherris, J.C. and Turch, M. 1966. Antibiotic susceptibility testing by a standardized single disc method. Am. J. Clin. Pathol. 45, 493-496.

Chavan, V.V., Digraskar, S.U., Dhone, S.N. and Hase, P.B. 2007. Observation on bubaline subclinical mastitis in and around Parbhani. Indian J. Field Vet. 3, 50.

Chopra, I. and Roberts, M. 2001. Tetracycline antibiotics: mode of action, applications, molecular biology, and epidemiology of bacterial resistance. Microbiol. Mol. Biol. Rev. 65 (2), 232260.

Cruickshank, R., Duguid, J.P., Marmion, B.P. 
and Swain, R.H.A. 1975. Medical Microbiology. Vol. II, 12 $2^{\text {th }}$ Ed., Crurchill Livingstone, New York, 3157p and 96-218p.

Fagiolo, A., and Lai, O. 2007. Mastitis in buffalo. Ital. J. Anim. Sci. 6, 200-206.

Javed, I. and Siddique, M. 1999. Some epidemiological aspects of mastitis in cows and the characterization of the isolates. Pak. Vet. J. 19, 149-154.

Kalorey, D.R, Purohit, J.H. and Dholakia, P.M. 1983. Studies on incidence of subclinical mastitis, its etiology and in vitro sensitivity of isolates. Indian J. Anim. Sci. 53, 961-963.

Kaya, O., Kirkan, S. Gulal, M. and Unal, B. 2000. Identification and antibiotic susceptibility of microbes causing mastitis in dairy cows. Vet. Bull. 70, 290.

Kuang, Y., Tani, K., Synnott, A.J., Ohshima, K., Higuchi, H., Nagahata, H. and Tanji, Y.2009. Characterization of bacterial population of raw milk from bovine mastitis by culture-independent PCRDGGE method. J. of Biochem. Eng. 45, $76-81$

Mungube, E.D., Tenghagen, B.A., Regassa, F., Kyule, M.N., Shiferaw, Y., Kassa, T., Baumann, M.P.O. 2005. Reduced milk production in udder quarters with subclinical mastitis and associated economic losses in crossbred dairy cows in Ethiopia. Trop Anim Health Prod. 37(6), 503-512.

Nickerson, S.C. and Stephen, C. 2009. Control of heifer mastitis: Antimicrobial treatment-An overview. Vet. Microbiol. 134, 128-135.

Nickerson, S.C., Paape, M.J. and Ziv, G. 1986. Mammary leukocyte response to drug therapy. J. Dairy Sci. 69, 1733.

Pankaj, A. S., Chhabra, R., and Sindhu, N. 2013. Sub-clinical mastitis in Murrah buffaloes with special reference to prevalence, etiology and antibiogram.
Buffalo Bull. 32(2), 107-115.

Petzer, I.M., Karzis, J., Watermeyer, J.C, Vander Schans, T.J. and Van Reenen, R. 2009. Trends in udder health and emerging mastitogenic pathogens in South African dairy herds. J. S. Afr. Vet. Assoc. 80, 17-22.

Raberg, L., Sim, D. and Read, A.F. 2007. Disentangling genetic variation for resistance and tolerance to infectious diseases in animals. Sci. 318, 812-814.

Rani, N.L., Manda, S., Suresh, K. and Makkenasreenu. $2008 . \quad$ An epidemiological study of mastitis in buffaloes. Indian Vet. J. 85, 1350-1351.

Ranjan, R., Gupta, M.K., Singh, S. and Kumar, S. 2010. Current trend of drug sensitivity in bovine mastitis. Vet. World. 3, 17-20.

Reshi, A.A., Husain, I., Bhat, S.A., Rehman, M.U., Razak, R., Bilal, S. and Mir, M.R. 2015. Bovine mastitis as an evolving disease and its impact on the dairy industry. Int. J. of Curr. Res. Rev. 7, 48 .

Schalm, O.W., Carol, E.J. and Jain, N.C. 1971. Bovine mastitis; Lea and Febiger, Philadelphia.

Sharma, A., Chhabra, R., Singh, M., and Charaya, G. 2018. Prevalence, etiology and antibiogram of bacterial isolates recovered from mastitis of buffaloes. Buff. Bull. 37(3), 313-320.

Sharma, N., Maiti, S.K. and Sharma, K.K. 2007. Prevalence, Etiology and Antibiogram of Microorganisms associated with subclinical mastitis in buffaloes in Durg, Chhatisgarh State (India). Int. J. Dairy Sci. 2, 145-151.

Shome, B.R., Das Mitra, S., Bhuvana, M., Krithiga, N., Velu, D., Shome, R. and Rahman, H. 2011. Multiplex PCR assay for species identification of bovine mastitis pathogens. J. App. Microbiol. 6, 1349-1356.

Sindhu, N., Sharma, A., Nehra, V. and Jain, 
V.K. 2009. Occurrence of subclinical mastitis in cows and buffaloes at an organised farm. Har. Vet. 48, 85-87.

Singh, P.J. and Singh, K.B. 1994. Study on economic losses due to mastitis in India. J. Dairy Sci. 47, 265-271.

Sumathi, B.R., Veeregowda, B.M. and Gomes, R.A. 2008. Prevalence and antimicrobial profile of bacterial isolates from clinical bovine mastitis. Vet. World, 1, 237-238.

Tenhagen, B.A., Hansen, I., Reinecke, A. and Heuwieser, W. 2009. Prevalence of pathogens in milk samples of dairy cows with clinical mastitis and in heifers at first parturition. J. Dairy Res. 76, 179-187.

Wanasinghe D.D. 1985. Mastitis among buffalos in Sri Lanka. Proc. First World Buffalo Congr. Cairo, Egypt. 4, 13311333.

Zecconi, A., Piccinini, R. and Fox, K.L. 2003. Epidemiologic study of intramammary infections with Staphylococcus aureus during a control programme in nine commercial dairy herds. J. Am. Vet. Med. Assoc. 223, 684-688.

\section{How to cite this article:}

Rajesh Chhabra, Garima Shrinet, Rahul Yadav and Saurab Jyoti Talukdar. 2020. Prevalence of Sub Clinical Mastitis in an Organized Buffalo Dairy Farm along with Antibiogram. Int.J.Curr.Microbiol.App.Sci. 9(01): 1605-1612. doi: https://doi.org/10.20546/ijcmas.2020.901.176 